\title{
At Home in the World: A Memorial Tribute to Donald Capps (1939-2015)
}

\author{
Robert C. Dykstra ${ }^{1} \cdot$ Nathan Carlin $^{2}$
}

Published online: 11 December 2015

(C) Springer Science+Business Media New York 2015

In the concluding chapter of 100 Years of Happiness: Insights and Findings from the Experts, a book that considers what constitutes a happy life from perspectives of distinguished philosophers, economists, psychologists, and others who wrote on the nature of happiness over the course of the past century, pastoral theologians Donald Capps and Nathan Carlin (Carlin and Capps 2012) venture to offer their own reflections on the keys to a happy life. Don's list initially features the biblically perfect number of seven keys to happiness. On further reflection, however, he finds himself drawn to adding two more, hinting perhaps that he is an especially happy person, for a grand total of nine, in his words, "Things That Make Me Happy” (pp. 186-187). In this memorial essay, we draw on Don's keys to happiness to frame a narrative of his life and his impact on countless other lives, including our own. Though Don would not have assumed that others' lists of key factors for happiness would mirror in any way his own, he likely would hope that in considering his keys others might be inspired to articulate theirs.

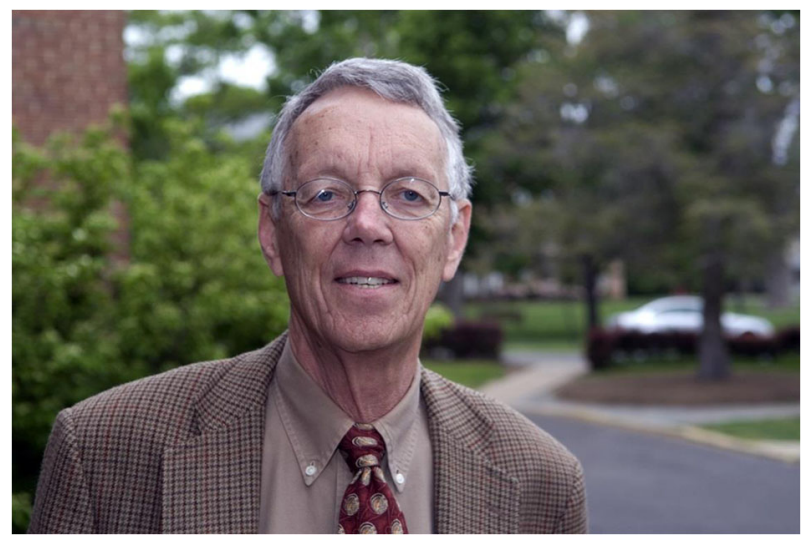

Robert C. Dykstra

robert.dykstra@ptsem.edu

Nathan Carlin

Nathan.Carlin@uth.tmc.edu

1 Princeton Theological Seminary, P.O. Box 821, Princeton, NJ 08542-0803, USA

2 McGovern Center for Humanities and Ethics, The University of Texas Medical School at Houston (UTHealth), 6431 Fannin Street, JJL 410, Houston, TX 77030, USA 


\section{The first key to happiness}

Don describes his first key to happiness as "a personal relationship with my wife that is based on love, trust, and acceptance" (Carlin and Capps 2012, p. 186).

Don's first words to Karen Virginia Docken, whom he met at age 24 when they were both working over a summer break at Emanuel Hospital near his parents' home in Portland, Oregon, were, "Hey, Karen, wait up!" (Karen Capps to Robert Dykstra, personal conversation, August 31, 2015). As it turned out, she waited up.

At the point in his life when he met Karen, Don was struggling over his vocational trajectory. Since childhood, he had felt what he described as "some sort of "call' to ministry" (Donald Capps to Nathan Carlin, personal correspondence, October 6, 2004). A high school teacher encouraged Don, who at 16 won a national creative writing award for a fictional short story, to attend Reed College in Portland, where, she said, she could secure for him a scholarship. But Don's mother discouraged him from applying, fearing in the era of the Joseph McCarthy Committee hearings that Reed's faculty had been "overrun by Communists" (Carlin 2014, p. 26, n. 37). Don reluctantly heeded his mother's advice, though without sharing her convictions, and attended instead three other colleges in Portland and Washington State over the next 3 years. He graduated in 1960 from Lewis and Clark College, with majors in both philosophy and English. Three years later, at the time he first met Karen, he had completed a Bachelor of Divinity degree at Yale Divinity School, and, in the fall of 1963, having also been accepted into a $\mathrm{PhD}$ program in English literature at Tufts University, he entered a PhD program in philosophy at the University of California, Berkeley. After only several weeks of seminars in that program and still uncertain of his vocational direction, Don asked and was allowed to transfer to UC Berkeley's PhD program in English. Again, however, something did not quite fit for him, so after just one semester of seminars, and missing Karen's companionship, he decided to take some time away from school, return to Portland to assist a pastor in a local Lutheran congregation, spend more time with Karen, and see what would come next (Karen Capps to Robert Dykstra, personal conversation, October 21, 2015).

What came next was that Don and Karen were wed on August 22, 1964, and they moved together across the country for him to begin a second degree-program - a Master of Sacred Theology - at Yale. Though Don considered concentrating in Christian ethics, he became intrigued by, and eventually threw in his lot with, a particular professor of pastoral psychology, James E. Dittes.

Previously, as a Bachelor of Divinity student at Yale, Don had gone to Dittes's office on the off chance that he could avoid taking the required course in pastoral care. Dittes reacted without hint of indignation to this request and, to Don's great surprise, granted the waiver. The professor showed no evidence of needing to defend the necessity of his course. As Don was leaving his office, Dittes said to him, "If you ever want to talk, stop by and see me."

Returning then to Yale a year later to begin the STM and confused by his dissatisfaction with the UC Berkeley programs, Don did stop by to speak with Dittes, having remembered his kind disposition and dispensation. Thus began what became for both men a mutually rewarding, lifelong friendship and productive professional collaboration in pastoral psychology and the psychology of religion. Both men would serve, for example, as editor of the Journal of the Scientific Study of Religion (Don from 1983 to 1988) and also as president of the Society for the Scientific Study of Religion (Don from 1990 to 1992). By allowing him to avoid a first course in pastoral theology, Dittes unwittingly set in motion a journey that would lead Don to become one of the most influential figures in the discipline. 
In the preface to Men, Religion, and Melancholia (Capps 1997b), Don likens his relationship with Dittes to that of James Boswell with Samuel Johnson of an earlier century. In writing this book, which many consider to be one of his most original and insightful, Don said, "I was frequently aware of carrying on a conversation in my mind with James E. Dittes, who introduced me to the psychology of religion and thus enabled me to find my niche in life, and who has subsequently extended to me the kindnesses to which I allude in the second half of the book's conclusion," which concerned those of Johnson to Boswell (p. xiii). Dittes, Don wrote elsewhere, was one "who upholds by letting be" (Capps 1995, p. iv).

Thus began Karen and Don's first year of marriage. Over the decades that would followwhich, after their 50th wedding anniversary in 2014 they would joke about as their "50-odd years of marriage," with the question unresolved as to whether a hyphen should link " 50 " and "odd" - they found in each other the closest of friends. In 1993, Don dedicated to Karen, who holds an EdD in elementary and early childhood education, his book The Poet's Gift: Toward the Renewal of Pastoral Care (Capps 1993b) with the simple inscription, "To Karen, who worries for us." Later, in the preface to Men, Religion, and Melancholia (Capps 1997b), Don acknowledges his appreciation for Karen, "the one," he says, "to whom I make reference in chapter five when I proclaim: 'And how fortunate the son who finds in this immense world of objects one whom he can love and, in loving, can regain his capacity to believe"' (p. xiii). More recently, in the acknowledgments to his book At Home in the World: A Study in Psychoanalysis, Religion, and Art (Capps 2013), Don thanks Karen for her "friendship and love": "While writing this book, I was especially conscious of the fact that she has been my beacon of hope ever since we met in the summer of 1963. Readers familiar with John Bunyan's The Pilgrim's Progress will understand what I mean when I say that she has been the very personification of faith and hope throughout my life's journey" (p. ix).

\section{The second key to happiness}

The second key to happiness for Don was the fact that he had "a good feeling about my role as a father when our son was growing up and how we relate to one another now" (Carlin and Capps 2012, p. 186).

As Karen noted to Don's brothers as they were preparing a memorial service for Don and as Don's publication record attests - 31 monographs, 7 coauthored books, 14 edited and coedited books, and 198 articles and counting - "Don lived to write" (Karen Capps to Douglas Capps, personal correspondence, September 25, 2015). This love for writing was something he shared with their son John, now a professor of philosophy at the Rochester Institute of Technology. As a high school student, John prepared a draft of his father's book Deadly Sins and Saving Virtues (Capps 1987) on his computer at a time when Don continued only to use a typewriter. On the acknowledgments page of the book, Don noted that if, according to Agatha Christie, "writing is murder," John was "an indispensable accomplice." Later, John would prepare the index for his father's The Depleted Self: Sin in a Narcissistic Age (Capps 1993a). Later still, father and son became accomplices again, first coediting a book on William James and John Dewey (Capps and Capps 2005), then coauthoring a philosophical book on jokes and logic (Capps and Capps 2009). In the dedication of Men, Religion, and Melancholia, Don writes:

I have profited from many personal conversations in recent years with students and colleagues on the topic of this book, but those that especially stand out in my mind are 
ones I had with John Capps, who sensed by the rather serious tone of our conversations that the topic of melancholy has for me a personal subtext, which mercifully remained, for the most part, unspoken but understood. For all that he has been and meant to me through the years, I dedicate this book in gratitude to him. (Capps 1997b, p. xii-xiii)

The dedication itself reads: "To John, from a grateful father" (p. 5).

\section{The third key to happiness}

Don describes the third component of his path to happiness as "a few good male friendships based on trust and a mutual sense of being supportive of one another" (Carlin and Capps 2012, p. 186).

Though shared laughter may have been the most striking feature of Don's male friendships, he took these friendships, and the life-giving nature of friendship itself, quite seriously. Quoting Ralph Waldo Emerson's (1983, p. 351) essay entitled "Friendship," Don endorsed Emerson's view that friendship has two basic elements: truth and tenderness. Elaborating on the truth essential to friendships, Don noted how often boys and men point out "that their close friends are persons they could tell everything and not feel any need or desire to hold anything back." He added that

it is virtually impossible to have really close friendships with other boys [and men] who do not accept them as they truly are, or in which they feel that they are required to adapt to a value system with which they are uncomfortable. Thus, truth is essential, and an important aspect of this truth is that one can be oneself. In fact, a close friendship is a means toward coming to know who one is, for, as Emerson also points out, "We must be our own before we can be another's." (Emerson 1983, p. 351, as cited in Dykstra et al. 2012, p. 104)

Don likewise speaks of the "deep sense of tenderness [evident] in the ways boys [and men] talk about their close friends," even while recognizing that it is not "easy for them to share their feelings with others" (Dykstra et al. 2012, p. 104). "Especially in these two ways - truth and tenderness - their friendships support Emerson's view that 'the essence of friendship is entireness, a total magnanimity and trust"' (Emerson 1983, p. 354, as cited in Dykstra et al. 2012, p. 104).

Don's friendships typically developed around close and usually painless collaboration on common writing and editing projects with professorial colleagues, including Dittes (Capps and Dittes 1990), Janet Liebman Jacobs (Capps and Jacobs 1995; Jacobs and Capps 1997), and Richard Fenn (Capps and Fenn 1992; Fenn and Capps 1992, 1995), and with former PhD students who had gone on to teach in other institutions. Reflecting at the time of Dittes's retirement, for example, Don writes: "Why do I recount these... occasions in which editing brought the two of us together? Because I think they illustrate how friendships - the male variety, at least — are formed in and through collaborative work" (Capps 2003, p. 47).

Although Don was, beyond even many men of his generation, quiet and emotionally reserved, those he privileged to count among his friends knew how tenderly he promoted, often in his writing, his unreserved faith in them. In the acknowledgments of At Home in the World, Don writes that he is "especially grateful to Robert Dykstra, Lewis Rambo, Allan Hugh Cole Jr., Nathan Carlin, and Carl Meier for their friendship over the years” (Capps 2013, p. ix). 
In dedicating another of his books, Jesus the Village Psychiatrist, to one of us, Robert, Don says:

When I was a boy, I loved to sing the hymn "Blest Be the Tie that Binds." All four stanzas were important to me then, but the lines that stood out for me, as though they were printed in boldface, were these: "The fellowship of kindred minds/Is like to that above." If so, Bob has afforded me a foretaste of what heaven promises to be. (Capps 2008a, p. ix)

Of coauthoring a recent book, The Gift of Sublimation: A Psychoanalytic Study of Multiple Masculinities, with another of us, Nathan, Don (Carlin and Capps 2015) writes:

Over the past decade, we have coauthored three books and twelve articles, and it has seemed almost effortless. We like to tell ourselves that this is because we, in our writing together, regress to what Erik H. Erikson has called "the play age," or roughly the age of three to five years old. When one observes the play of children at this age, one notices that they typically engage in making things and performing scenes (i.e., playacting), and sometimes they work alone and other times they work together. When they do not feel as though they are under the watchful and critical eye of the teacher or another classmate, there is an air of contentment among them, and a quiet sense of intimacy pervades the classroom. This is the feeling that we have experienced in our writing together. (p. xii)

Although Don was consistently averse to self-promotion, former protégés on the receiving end of the truth, tenderness, magnanimity, and trust he offered them returned the favor with genuine loyalty and affection. As was noted in a retirement tribute to Don:

At the opening luncheon of a conference [to honor Don's career] sponsored by Austin Seminary in the fall of 2008, a group of former doctoral students and colleagues teaching in seminaries around the nation and the world were invited to introduce themselves and to say how they had come to know Don and his work. The conference organizers expected this to be a polite few minutes of telling our names and our institutions and of briefly getting acquainted before turning to the "real" agenda of hearing scholarly papers on Don's work that each had prepared. But what we found instead around those lunch tables was story after story pouring out from participant after participant that took us far beyond the time allotted for introductions, in what can only be described as some fierce and spontaneous imperative on their parts to demonstrate their love and gratitude for a man who had somehow literally rescued each one of them, each one of us, from one or another of our past lives - for one who had reclaimed each of us from some tyranny of family, church, community, or usual way of conceiving of ourselves, our faith, our God, our calling, our scholarship. It could have gone on like that all afternoon, this desperate urgency to return thanks, to give Don thanks, for saving a life, an individual's life, our lives around those tables, again and again and again. (Dykstra 2009, p. 449)

More recently, in the immediate aftermath of Don's sudden death at age 76 on August 26, 2015, which resulted from injuries sustained in an automobile accident on Library Place in Princeton, New Jersey, Gordon Govens, a $\mathrm{PhD}$ candidate in church history at Princeton Theological Seminary, offered a similarly heartfelt outpouring of gratitude for Don's friendship, teaching, and life:

I just loved the man and who he was. He had the most amazingly kind and caring spirit, that which I have rarely if ever experienced in a person.... He is the first person to die in 
my life who was the source of my deep personal, spiritual change, who helped me grow closer to God and to help other people feel God's compassion and love through me and my care for them. Dr. Capps gave more to me than he took, and what he gave changed who I am. (Gordon Govens to Robert Dykstra, personal correspondence, August 28, 2015)

\section{The fourth key to happiness}

The fourth key to happiness for Don was "being productive in ways that are personally engaging and neither onerous nor stressful' (Carlin and Capps 2012, p. 186).

"Freud was once asked," Erik H. Erikson (1963) writes, "what he thought a normal person should be able to do well. The questioner probably expected a complicated answer. But Freud, in the curt way of his old days, is reported to have said: 'Lieben und arbeiten' (to love and to work)" (pp. 264-265). Don did both well. If the initial three keys focus on his ability to love others - his wife, his son, his friends-Don's fourth key emphasizes his love of work.

While well aware that work can be alienating, as Karl Marx pointed out, Don also knew, as Erikson observed, that work could be liberating. For Don, work was liberating. Karen noted that later in his life Don looked 10 years younger whenever he was sitting at his desk and working (Karen Capps to Robert Dykstra, personal conversation, September 3, 2015).

Don found liberating a regular routine of writing. He woke up each day at or before 4 a.m., and he wrote several hours every morning. With his writing already accomplished early in the day, he could give his full attention to other matters through the rest of the day. Students who met him for coffee or lunch, for example, often commented on how willing he was to talk with them for hours. He was organized with his time so that he could be generous with it.

Don also reduced the stress of writing by typically producing short books. He did not feel the need to say everything about a given topic, as if one could ever accomplish such a thing, and he did not feel as though his books needed to be perfect. Don usually wrote an entire book before approaching a publisher with an idea. Early in his career he felt the stress of procuring a contract for a book not yet written, so he decided never to do this again. Though writing is "murder" for many scholars, Don did little things - wrote early, wrote often, wrote short books, wrote without a contract - that enabled him to avoid the anxiety of writer's block.

But Don proved that even short books could have a big impact. When one of us, Robert, was visiting the London house, now the Freud Museum, where Freud spent the last year of his life after having fled Vienna following the German annexation of Austria in World War II, he discovered in the museum gift shop, on a small shelf of books bearing the label "Freud and Religion," two distinct titles by Don, both published by Yale University Press (Dykstra 2009, p. 448).

Given that he worked so hard and produced so much, it is difficult to summarize briefly the substance of Don's many intellectual contributions. It is easier to speak of his intellectual debts. There were three thinkers to whom he returned again and again throughout his life, mining the contours of their thought: Sigmund Freud, William James, and Erik Erikson. Don knew Erikson personally and they met on several occasions, including in Erikson's home. Of Erikson, Don recently wrote:

This book reflects my continuing indebtedness to Erik H. Erikson, [whose work I was introduced to] as a divinity-school student in the early 1960s. Now, some 50 years later, 
it is difficult to imagine what my life and work would have been like had I not become acquainted with his writings. Later, I also became [personally] acquainted with Erik Erikson and his wife, Joan Erikson. Readers of books often wonder what their authors are really like, and, most important, whether there is a congruence or consistency between the person and the author. My several encounters with Erik Erikson were deeply confirmatory in this regard. In fact, his ability to put me at ease in his presence and his openness to what I wanted to say enabled me to understand, in a new way, what it must have been like for young men and women to meet and talk with Jesus. (Capps 2014a, p. xiii)

Other key mentors, in addition to Dittes, included Peter Homans, to whom Don (Capps 2001, p. vii) attributed his close reading of Freud's texts; David Bakan, "who stimulated [Don's] interest in the psychoanalysis of the Bible"; and Paul W. Pruyser of the Menninger Clinic in Topeka, with whom Don "formed an invaluable collegial relationship during [their] mutual involvement in the Society for the Scientific Study of Religion." Of his relationship with Pruyser, Don wrote: "It seemed that we were the Society's lone defenders of psychoanalysis, a fact we lamented over leisurely dinners in otherwise barren surroundings" (Capps 2001, p. vii).

As difficult as it is to summarize the intellectual contributions of the most prolific writer in the history of the modern discipline of pastoral theology, two key themes do emerge. Chief among these is what William James (1956, pp. 255-262) once referred to as "the importance of individuals." Over the course of his nearly 50 years of publishing, Don wrote about individuals as diverse as Jesus, Augustine, Jonathan Edwards, John Henry Newman, Phillips Brooks, and Orestes Brownson, as well as about William James, Norman Rockwell, and John Nash, to name just a few. The Individual and His Religion by Gordon Allport (1950) stood out for Don as an important book. He likewise frequently cited this passage from William James, who recounts overhearing an "unlearned carpenter" doing some repairs in James's house: "There is very little difference between one man and another," the carpenter said, "but what little there is, is very important" (James 1956, p. 256, emphasis in original).

While many in pastoral theology in recent decades have been emphasizing social context, which likewise mattered a great deal to Don, he nonetheless underscored the importance of psychology, specifically of the kind that attends to the particularities of the individual. At a time when historians might consider passé the writing of biographies, when anthropologists and sociologists focus on groups and cultures, and when those offering various forms of cultural criticism focus on structures of power, Don urged psychologists of religion and pastoral theologians to retain their historic emphasis on the inner experiences and struggle for life of individuals (see Capps and Jacobs 1995).

Don's intellectual commitment to the importance of the individual carried over into the way he treated others, in particular, as noted above, his students. He loved teaching. He once told one of us, Robert, that he chose to take semester- rather than year-long sabbaticals because he would miss being away from students for an entire year. Students who took a course from Don discovered that his comments on their papers far exceeded any feedback they previously had come to expect from professors. It was typical for him to offer four pages of encouraging and detailed commentary on a student's eight-page paper. These copious comments and this kind of attention helped many of his students to shape regular course papers into their first published journal articles.

A second, and related, theme in Don's work is the value of introspection. In an essay on introspection, Don notes that William James, in The Principles of Psychology, "suggests that psychology has three methods of investigation, the experimental, the comparative, and introspective observation, and it is the latter that 'we have to rely on first and foremost and 
always" (Capps 1997c, pp. 38-39, citing James 1950, p. 185). When Alice Miller, a psychoanalyst of international renown who wrote prolifically about child abuse, once asked Don how he was able to come to such original insights about Jesus and other figures such as Augustine, Don's answer was, in a word, introspection. Miller publicly praised him for his creativity and courage in her book The Truth Will Set You Free: Overcoming Emotional Blindness and Finding Your True Adult Self (Miller 2001, pp. 92-93).

Don was an iconoclast, his work at times controversial. In one of his books on Jesus, he argued that Jesus was an illegitimate son of Mary, possibly conceived as a result of rape and most likely never adopted by Joseph (Capps 2000, especially pp. 153-163). In his presidential address to the Society for the Scientific Study of Religion in 1992, Don (Capps 1992, pp. 1-14) titled his lecture "Religion and Child Abuse: Perfect Together." This lecture became the basis for his deeply personal The Child's Song: The Religious Abuse of Children (Capps 1995).

But he also dedicated his life to being genuinely helpful and embraced the term "pastoral," if not often the term "theological," to describe his life and work. There were two professional "selves" that lived in creative tension within him, namely, his psychoanalytic self and his pastoral care self. His iconoclastic spirit is most often reflected in his writings in psychoanalysis, whereas his more conventional self is evident in writings on the nature and work of pastoral care and counseling. At times, however, he would invoke the psychology of religion, particularly insights of William James on themes of personal agency and hope (Capps 1997a, pp. 139-149; see also Capps 1999, pp. 23-44), to unite these distinctive professional selves. On the morning of his death, for example, Don was reviewing page proofs for a new book entitled The Religious Life: The Insights of William James (Capps 2015), which introduces seminarians to James's The Varieties of Religious Experience. In the acknowledgments, he writes:

As I consider the fact that I have dedicated my life, vocationally speaking, to the religious life, I am deeply grateful for William James's ability to see and understand the inner nature of the religious life, and for his capacity to express this understanding in a way that confirms that a life dedicated to the religious life is well worth living. (Capps 2015, p. vii)

Though not always fully appreciated by others as such, Don's was a profoundly religious life, and he dedicated himself to preparing thousands of students for ministry and teaching. Just prior to completing his doctoral degree at the Divinity School of the University of Chicago in 1970, he began his teaching career as an instructor in the Department of Religious Studies at Oregon State University in 1969; he returned to teach at the University of Chicago as an instructor and then assistant professor from 1969 to 1974, during which time he also prepared, under the kindly guidance of Joseph Sittler, a Lutheran theologian at the Divinity School, for his ordination in 1972 as a minister in the Evangelical Lutheran Church in America; next, he taught as an associate professor in the Department of Religious Studies at the University of North Carolina at Charlotte until 1976; and, penultimately, he taught from 1976 to 1981 as an associate and then full professor at the Graduate Seminary of Phillips University. In 1981, at age 42, Don arrived at Princeton Theological Seminary to begin teaching as the William Harte Felmeth Professor of Pastoral Theology. Especially in these latter two positions, at Phillips and at Princeton, he came most fully into his vocation as one committed to helping seminarians treasure and mine their own unique, sometimes unusual, understandings and experiences of faith and life in service to God in ministry. He received an honorary doctorate (ThD) from the University of Uppsala, Sweden, in 1989. He retired at age 70 from Princeton Seminary in 2009 and was accorded emeritus status by its Board of Trustees. He continued to teach there each semester as an adjunct professor until the time of his death. 


\section{The fifth key to happiness}

The fifth key to happiness for Don involved "being appreciative and grateful for my life and not thinking about what might have been" (Carlin and Capps 2012, p. 186).

Because Don was always both so self-evidently grateful for his life and professionally successful, it is not altogether clear to us what he may have meant by the phrase "what might have been." But of gratitude for his life Don spoke often. One of his favorite Bible passages was Psalm 16:6: "The lines for me have fallen in pleasant places."

Don was profoundly grateful for his work at Princeton Seminary and spoke especially warmly of President James McCord, who brought him to Princeton as a full professor, honoring what Don had accomplished in previous teaching posts. He loved living on Nassau Street and in the town of Princeton. He treasured its bookstores and the local movie theater. He spoke of being grateful simply to live in this particular era of American history, commenting on a number of occasions, for example, about how amazed he was at the progress of medicine during his lifetime, and he took full advantage of this care. He once said to one of us, Nathan, that he thought air travel was "fun," though later in his life he traveled by plane only infrequently. He lived simply with few material possessions. His realtor once commented to another of us, Robert, that on preparing to list his house for sale she mistakenly thought that Don had already moved out, given how few clothes were in his closet. But he was, indeed, still living there. Just weeks before his death, he celebrated the birthday of one of his grandchildren with cupcakes from a local shop, and a photograph of the occasion captures the sheer delight on Don's face in the moment. He was at home in the world. He loved his life.

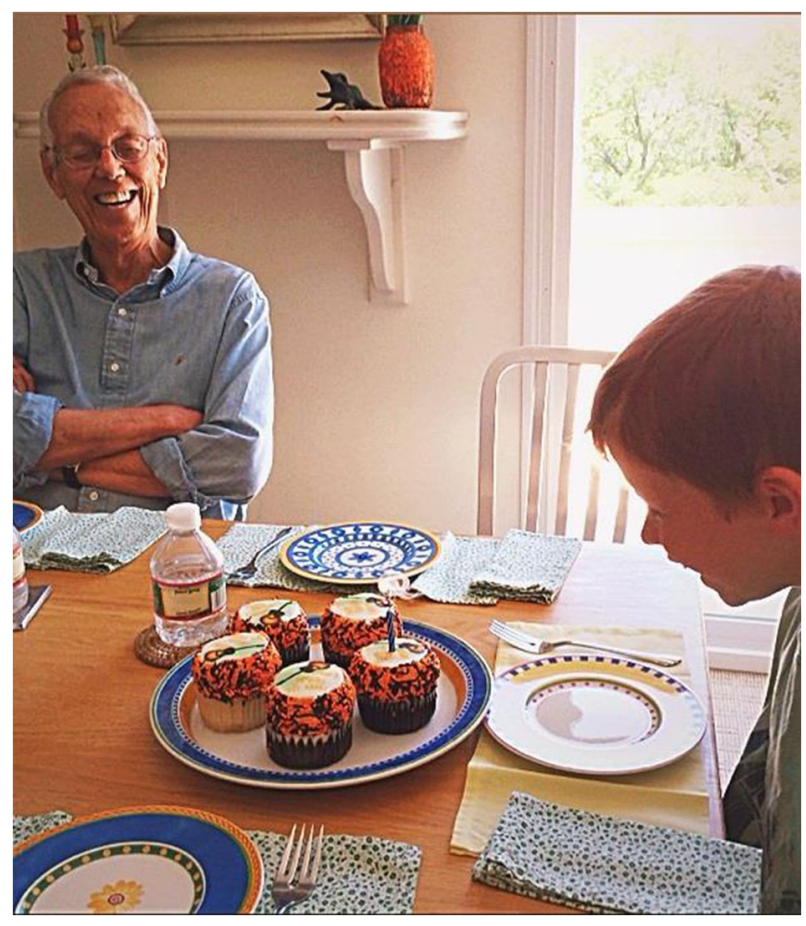




\section{The sixth key to happiness}

Don succinctly described his sixth key to happiness as experiencing "small but daily pleasures" (Carlin and Capps 2012, p. 186).

As a boy, Don took pride in being a Boy Scout. He enjoyed camping as a Scout and continued to do so with his wife and son when John was young. He enjoyed being organized with his time and being neat with his space, traits inculcated in him, perhaps, as a young Scout. As an adult his small but daily pleasures involved mundane things, such as getting enough sleep, eating cheap chocolate, and buying a morning cup of coffee at the Wawa market. He enjoyed not eating vegetables or, at least, joking about not eating them. He once wrote a poem, based on the hymn "Just As I Am, Without One Plea," about Thanksgiving dinner; his was entitled "Just As I Am, Without One Pea."

He and Karen would walk several miles each day at a local mall. Though cultured intellectuals sometimes lament the proliferation of shopping malls, preferring instead independent shops, Don, as an older adult, was grateful for a consistent place to walk in any season or weather. He could appreciate lowbrow movies such as Alvin and the Chipmunks but also enjoyed watching British murder mysteries on BBC. He and Karen often went to art museums. He took pleasure in nature, including nature preserves in Princeton. He appreciated getting a good deal, such as on the Dollar Menu at Wendy's. He welcomed talking with students oneon-one. He enjoyed correspondence, crafting letters and emails with care. Sleep, food, walks, nature, conversation, correspondence, organization, tidiness, frugalness, and work-simple daily moments gave Don great satisfaction and pleasure.

\section{The seventh key to happiness}

The seventh key to happiness for Don involved "focusing on the near rather than the distant future" (Carlin and Capps 2012, p. 186).

Don's reading of the happiness literature influenced him on this point, but this key to happiness likely also reflects his expertise on the life cycle. Writing in his 70 s, Don was acutely aware of the fact that his time was limited. He revealed publicly during meetings of the Group for New Directions in Pastoral Theology, an international scholarly conference he cofounded in 2009, that he expected to be able to continue to write only until around the age of 80 . The decade of his $70 \mathrm{~s}$ easily became his most prolific, when it was not unusual for him to produce several books per year. Focusing on the distant future would have meant not only contemplating a time of drawing closer to death but, perhaps more threatening for Don, a time in which he could no longer write.

Even when he was younger, however, he embraced this way of thinking. He learned, for example, to decline invitations to lecture around the country and the world. Because it was not unusual for these invitations to be issued as much as a year in advance, he found that he would spend the ensuing year worrying about what he would say, expending far more emotional energy than warranted by such events. Instead, he shifted his thinking, so far as he was able, to more immediate goals and was happier for it.

\section{The eighth key to happiness}

As noted, Don initially tried to contain his list of things that make for happiness to the biblically perfect seven. Finally, however, he could not keep himself from commending to his readers two 
additional keys. One of these, he writes, is "the importance of staying in touch with the happy boy who continues to live inside of [me]" (Carlin and Capps 2012, pp. 186-187).

The significance throughout the whole of one's life, even into older adulthood, of this close connection to the young child and the adolescent one once was, is something Don believed that the so-called experts in human happiness invariably overlooked. But "taking one's cues as an adult from the boy or girl you were many years ago" (Carlin and Capps 2012, p. 187) was for Don no exercise in nostalgia; instead, it was a tactic for survival and growth. This is because the child and adolescent still living within are often actually wiser and braver than the adult one has become. It is not that one looks back and chuckles at the naïveté of one's youthful self. Rather, Don claimed, the boy continued to inspire and guide him as a man.

That boy was born on January 30, 1939, in Omaha, Nebraska, where he lived at 5021 Spencer Street with his mother and father, Mildred and Holden Capps, along with three brothers, Walter, Roger, and Douglas, and his paternal grandfather. When Don was 14 and a sophomore in high school, his father, a Union Pacific Railroad accountant, accepted a job transfer and moved the family to Portland, where over the next years Don would attend two additional high schools (Dykstra et al. 2012, p. 92).

There were boys enough in his Omaha neighborhood to field entire baseball teams. Asked recently by Don's brother, Roger Capps, what position Don played, a former kid from the neighborhood recalled that Don usually played outfield, but, the man added, Don "always gave the appearance that he'd rather be home reading a good book!"

When Don was 10, his brother Roger happened upon him reading a Swedish Bible and asked him why. "What better way to learn the Swedish language?" Don replied. When he had finished reading "everything of interest in [his] neighborhood library," he would find his way downtown to Omaha's main library to read more books there (Douglas Capps to Robert Dykstra, personal correspondence, October 2, 2015).

But Don would also trace the headwaters of his theory of male melancholia, an exploration that would consume decades of his adult scholarly life, to the psychological and religious experiences of this inquisitive boy. Don recounted to psychoanalyst Alice Miller, who initiated a period of correspondence with him in 2005, that as the third of four sons he had found it "remarkably liberating" to discover, much later in his life, "incontrovertible evidence that [my mother] had wanted me to be a girl (after all, her first two children were boys)" and, in this, coming to understand "just how much of a disappointment I was to her." He reveals to Miller that his

own mentors were unable to free themselves from the powerful need to believe that our mothers had 'nothing but love for us,' and... I thought they needed to maintain this myth about our mothers' feelings for us in order to maintain an idealized myth about ourselves. I suggested that this was also true of popular writers on books for men, like Frank Pittman in Man Enough and William Pollack in Real Boys. (Donald Capps to Alice Miller, personal correspondence, July 29, 2005)

Miller responded by linking Don's revelation of his mother's disappointment in him to his capacity to generate courageous theological insights in his writings:

Reading your books, I have sometimes wanted to ask you: How does it come that you take the liberty to see and the courage to say the "forbidden things"? How did you manage to write about Augustine, about Jesus and so many others and to stay true to the facts? So it came not to me as a surprise to read in your letter that you are aware of 
having been a disappointment to your mother just in the first moment of your life. To feel this is very painful and thus most people deny this pain; they try very hard to become what their mother wanted them to be.... The courage to see is maybe nothing else than the courage to feel the plight of our own history. Everything else is easier to bear. (Alice Miller to Donald Capps, personal correspondence, August 9, 2005)

Don could also write openly of ambivalent feelings for his father. In a chapter on Jesus' childhood in The Child's Song, he describes engaging in a process of personal introspection in an effort to understand the inner experience of the boy Jesus:

What is involved for one who seeks to get inside Jesus' own experience as a child is a kind of self-abandonment, that is, an imaginative entry into Jesus' own situation when I personally take the view of a child who is aware of his illegitimacy, and who has already begun to reflect on the fateful implications of this inexorable fact for his life. If this were my situation, how would I receive it? How would I experience it? How would I respond? This has proved to be a difficult, even painful exercise, as it has necessarily involved recalling experiences in my own childhood which most nearly approximate his experience. (Capps 1995, p. 112)

What Don initially discovered in this exercise, he writes, was both a desire "to have experienced my own father more forcefully than I did," accompanied by a "profound gratitude... for my father's dependability and personal sacrifices for me." But on further introspection, "a rather darker atmosphere emerged":

Surely not the sense that my father was evil or despicable, or that he had violated or abused my mother. No, not that. But the sense, nevertheless, that it may have been better for this child to have had a different man for his father. Such feelings, long repressed, came to my awareness, and I re-experienced what must have been one of the most painful experiences of childhood and possibly the strongest impetus for repressing our childhood experiences, that of feeling shame not for myself but for a parent whom I deeply loved. (Capps 1995, p. 113)

It was something of this "desire to be another man's son" that Don came to view as the inspiration for the boy Jesus to view "God as a personal father, a father who effectively replaces human fathers in his understanding of himself as someone's son. He would know himself as the son of Abba, and thus, as no longer illegitimate or adopted. He was the true son of Abba and thus of no other" (Capps 1995, p. 114; see also Carlin 2014, pp. 30-31).

There was more. The boy within Don likewise reminded the adult man and scholar to be cautious about placing his trust in human institutions. When Don was in the sixth grade, he was a member of his school's safety patrol and proud to be one of two students assigned to patrol the intersection closest to the school and the one therefore with the most traffic. He was also responsible for raising and lowering the United States flag, a job he took quite seriously. His peers honored Don by electing him lieutenant of the patrol for the seventh grade, the group's highest office. But "another boy's mother went to the school principal and told him that she wanted her son, Larry, to be the lieutenant," and the principal agreed to her request. Don, subsequently assigned to Larry's former post several blocks away from the school, was humiliated by the demotion and quit the patrol altogether. Reflecting on this series of events years later, Don reveals that "the experience created a deep suspicion of how human organizations work” (Dykstra et al. 2007, pp. 166-167; see also Carlin 2014, pp. 31-32). 
In an autobiographical chapter in The Faith and Friendships of Teenage Boys (Dykstra et al. 2012, pp. 87-106), and more recently in Still Growing: The Creative Self in Older Adulthood (Capps 2014b, pp. 14-31), Don makes explicit what he describes as this "rather odd" claim that the boy-his younger self-serves as mentor to the older adult man he has become. After all, is not a mentor supposed to be older than the protégé? But in a reframing characteristic of much of Don's life and work, he goes on to claim that, in a sense, the boy within him is older than the man, in that the boy "represents an earlier era and expresses convictions that $\mathrm{I}$, the older man, have found invaluable in my own journey from middle to older adulthood" (Capps 2014b, p. 26). The boy Don often experienced a secure sense of where he was going in life that the older man, less certain of his direction, found worth trusting. Don found in childhood poems he had written, along with other scrapbook items he had preserved, a boy hopeful about the future. He recognizes that

it would be easy for me, the older man, to say that [the hopeful boy] is in for a rude awakening, that there will come a day when the anticipated tomorrow is worse-much worse - than today, which is already bad enough. But why should I assume that he is utterly naïve when, more than likely, he is simply a boy with an irrepressible will to believe? (Capps 2014b, p. 28, referring to James 1956, pp. 1-31)

Don draws strength from this younger boy's hopeful self and willing self to facilitate, he says, his transition to older adulthood.

But finally he recognizes a shift from his younger self as mentor to experiencing him as traveling companion to his older adult self, even as Faithful and Hopeful were traveling companions to Christian in Bunyan's Pilgrim's Progress (Capps 2014b, p. 30). The companionship of his younger self offers Don, he says, a sense of vitality that "derives from the feeling that... we are like the two travelers on the road to Emmaus. As we walk together, we find ourselves 'talking with each other about all these things that had happened"' (Luke 24:14) (Capps 2014b, pp. 30-31), especially "the sense of an overwhelming mixture of [tears, terror, and wonder] befitting the depth and enormity of the experience that they could not have anticipated in a thousand years" (Dykstra et al. 2012, p. 102, emphasis in original).

\section{The ninth key to happiness}

One final key to happiness for Don was "having an ironic view of life," which, he felt, "is critical to being a basically happy person" (Carlin and Capps 2012, p. 186).

For this reason he was especially drawn to the parables of Jesus. Don made the case for a parabolic approach to pastoral care in a number of his books, including Biblical Approaches to Pastoral Counseling (Capps 1981), Pastoral Care and Hermeneutics (Capps 1984), and Reframing: A New Method in Pastoral Care (Capps 1990). In his understanding of parables Don was influenced by the work of John Dominic Crossan (1975), who pointed out that parables, as a genre, are not allegories, and that their point is not to teach by means of metaphor. Rather than conveying a specific moral lesson, parables are meant to open us up to a new way of seeing. Seeing things anew, Don taught us, often requires a sense of irony.

In The Poet's Gift (Capps 1993b), Don argues that the poem is the most direct descendent of the parable and that poetry therefore holds great promise for pastoral care. Poetry opens us to new ways of seeing and experiencing God. One of Don's favorite poets was William Stafford, his undergraduate professor at Lewis and Clark College, and he focuses on his work in the 
book. This poem by Stafford (1977, p. 234; cited in Capps, 1993b, p. 167), titled "The Little Ways That Encourage Good Fortune," was especially meaningful to him:

Wisdom is having things right in your life and knowing why.

If you do not have things right in your life you will be overwhelmed:

you may be heroic, but you will not be wise.

If you have things right in your life

but do not know why,

you are just lucky, and you will not move

in the little ways that encourage good fortune.

The saddest are those not right in their lives

who are acting to make things right for others:

they act only from the self-

and that self will never be right:

no luck, no help, no wisdom.

Don had many things right in his life and knew why. This little thing in particular-having an ironic view of life - encouraged the good fortune of not taking himself or the problems he faced too seriously. He had a great sense of humor; he knew how to laugh.

One gift he gave the Princeton Seminary community was in creating a group he called the Bad Poets' Society, which Don served for years as unelected secretary pro tem and chief newsletter editor. He wrote unceasing streams of bad poetry himself and invited any interested others to join in.

As a sometimes chair of various faculty committees at Princeton Seminary, Don was fond of quoting Proverbs 18:2: "A fool takes no pleasure in understanding, but only in expressing his opinion." He would follow this reading with this prayer: "Dear Lord, since it is a known fact that there is a direct correlation between the expressing of opinions and the length of committee meetings, help us to take pleasure in understanding so that our meetings will be nice and short. Amen."

Humor held deep significance for Don. In Religious Mourning, Nathan Carlin (2014) examines how Don's life experiences and the major themes of his work were inextricably intertwined. Carlin argues that Don turned to humor for dealing with his own personal struggles with melancholia. Don suffered many personal losses during the decade of his 50s, including the death of a brother and the death of his father, and it was after these numerous losses that he turned to studying humor. He wrote two monographs on humor-A Time to Laugh: The Religion of Humor (Capps 2005) and Laughter Ever After: Ministry of Good Humor (Capps 2008b) — as well as a book coauthored with his son, previously noted, entitled You've Got to Be Kidding: How Jokes Can Help You Think (Capps and Capps 2009). As also noted above, one of Don's most original ideas was his male melancholia theory, which he developed and modified over the course of two decades. One striking aspect of this development is his concluding that humor, if not an actual cure for melancholia, is a pretty reliable remedy.

Don was quick to find humor in almost everything, including and especially in his work. So it seems best to close with this joke, found in Don's coauthored book with his son:

An angel appears at a faculty meeting and tells the dean that in return for his unselfish and exemplary behavior, the Lord will reward him with his choice of infinite wealth, 
wisdom, or beauty. Without hesitating, the dean selects infinite wisdom. "Done!" says the angel, and disappears in a cloud of smoke and a bolt of lightning. Now, all heads turn to the dean, who sits surrounded by a faint halo of light. One of his colleagues whispers, "Say something." The dean [—newly endowed with infinite wisdom- - sighs and says, "I should have taken the money." (Capps and Capps 2009, p. 6)

Acknowledgments William Stafford, "The Little Ways That Encourage Good Fortune" from Ask Me: 100 Essential Poems. Copyright (C) 1973, 2014 by William Stafford and the Estate of William Stafford. Reprinted with the permission of The Permissions Company, Inc. on behalf of Graywolf Press, Minneapolis, Minnesota, www.graywolfpress.org. The photograph of Donald Capps is courtesy of Princeton Theological Seminary (photographer credit: C. Nolan Huizenga). The photograph of Donald Capps with his grandson is courtesy of John Capps.

\section{References}

Allport, G. (1950). The individual and his religion: A psychological interpretation. New York: Macmillan.

Capps, D. (1981). Biblical approaches to pastoral counseling. Philadelphia: Westminster Press.

Capps, D. (1984). Pastoral care and hermeneutics. Philadelphia: Fortress Press.

Capps, D. (1987). Deadly sins and saving virtues. Philadelphia: Fortress Press.

Capps, D. (1990). Reframing: A new method in pastoral care. Minneapolis: Fortress Press.

Capps, D. (1992). Religion and child abuse: perfect together. Journal for the Scientific Study of Religion, 31(1), $1-14$.

Capps, D. (1993a). The depleted self: Sin in a narcissistic age. Minneapolis: Fortress Press.

Capps, D. (1993b). The poet's gift: Toward the renewal of pastoral care. Louisville: Westminster John Knox Press.

Capps, D. (1995). The child's song: The religious abuse of children. Louisville: Westminster John Knox Press.

Capps, D. (1997a). The letting loose of hope: where psychology of religion and pastoral care converge. The Journal of Pastoral Care \& Counseling, 51(2), 139-149.

Capps, D. (1997b). Men, religion, and melancholia: James, Otto, Jung, and Erikson. New Haven: Yale University Press.

Capps, D. (1997c). Shame, melancholy, and the introspective method in the psychology of religion. In J. Belzen, \& O. Wikstrom (Eds.), Taking a step back: Assessments of the psychology of religion (pp. 37-54). Uppsala: Acta Universitatis Upsaliensis.

Capps, D. (1999). From mystical moment to therapeutic method: connections between psychology of religion and pastoral counseling. Pastoral Psychology, 48(1), 23-44.

Capps, D. (2000). Jesus: A psychological biography. St. Louis: Chalice Press.

Capps, D. (2001). Freud and Freudians on religion: A reader. New Haven: Yale University Press.

Capps, D. (2003). James E. Dittes: a professional portrait. Pastoral Psychology, 52(1), 17-49.

Capps, D. (2005). A time to laugh: The religion of humor. New York: Continuum.

Capps, D. (2008a). Jesus the village psychiatrist. Louisville: Westminster John Knox Press.

Capps, D. (2008b). Laughter ever after: Ministry of good humor. St. Louis: Chalice Press.

Capps, D. (2013). At home in the world: A study in psychoanalysis, religion, and art. Eugene: Cascade Books.

Capps, D. (2014a). The resourceful self: And a little child shall lead them. Eugene: Cascade Books.

Capps, D. (2014b). Still growing: The creative self in older adulthood. Eugene: Cascade Books.

Capps, D. (2015). The religious life: The insights of William James. Eugene: Cascade Books.

Capps, J., \& Capps, D. (2005). James and Dewey on belief and experience. Urbana: University of Illinois Press.

Capps, J., \& Capps, D. (2009). You've got to be kidding! How jokes can help you think. Chichester: WileyBlackwell.

Capps, D., \& Dittes, J. E. (Eds.) (1990). The hunger of the heart: Reflections on the confessions of Augustine. Monograph series number 8. West Lafayette: Society for the Scientific Study of Religion.

Capps, D., \& Fenn, R. K. (Eds.) (1992). Individualism reconsidered: Readings bearing on the endangered self in modern society. Monograph number 1. Princeton: Princeton Theological Seminary.

Capps, D., \& Jacobs, J. (1995). The struggle for life: A companion to William James's The Varieties of Religious Experience. Monograph number 9. West Lafayette: Princeton Theological Seminary and the Society for the Scientific Study of Religion. 
Carlin, N. (2014). Religious mourning: Reversals and restorations in psychological portraits of religious leaders. Eugene: Wipf and Stock.

Carlin, N., \& Capps, D. (2012). 100 years of happiness: Insights and findings from the experts. Santa Barbara: Praeger.

Carlin, N., \& Capps, D. (2015). The gift of sublimation: A psychoanalytic study of multiple masculinities. Eugene: Cascade Books.

Crossan, J. D. (1975). The dark interval: Towards a theology of story. Niles: Argus Communications.

Dykstra, R. (2009). A judicious frame of mind: a tribute to Donald Capps. Pastoral Psychology, 58(5), 447-450.

Dykstra, R., Cole, A., \& Capps, D. (2007). Losers, loners, and rebels: The spiritual struggles of boys. Louisville: Westminster John Knox Press.

Dykstra, R., Cole, A., \& Capps, D. (2012). The faith and friendships of teenage boys. Louisville: Westminster John Knox Press.

Emerson, R. W. (1983). Emerson: Essays and lectures (Joel Porte, Ed.). New York: W. W. Norton \& Co.

Erikson, E. (1963). Childhood and society (2nd ed.). New York: W. W. Norton \& Co.

Fenn, R. K., \& Capps, D. (Eds.) (1992). The endangered self. Monograph number 2. Princeton: Princeton Theological Seminary.

Fenn, R. K., \& Capps, D. (Eds.) (1995). On losing the soul: essays in the social psychology of religion. Albany: State University of New York Press.

Jacobs, J. L., \& Capps, D. (Eds.) (1997). Religion, society, and psychoanalysis: Readings in contemporary theory. Boulder: Westview Press.

James, W. (1950). The principles of psychology (vol. 1-2). New York: Dover Publications.

James, W. (1956). The will to believe and other essays in popular philosophy. New York: Dover Publications.

Miller, A. (2001). The truth will set you free: Overcoming emotional blindness and finding your true adult self. New York: Basic Books.

Stafford, W. (1977). Stories that could be true: New and collected poems. New York: Harper \& Row. 